\title{
Effectiveness of Environmental Policies Adopted by the Tunisian Industrial Company
}

\author{
Fakhfakh Hamadi ${ }^{1}$, Amara Tijani ${ }^{2}$ and Ben Ali Tarek ${ }^{2}$ \\ ${ }^{1}$ Faculté des Sciences Economiques et de Gestion, Université de Sfax, Tunisie \\ ${ }^{2}$ Institut Supérieur d’Administration des Entreprises, Université de Gafsa, Tunisie
}

\begin{abstract}
The environment changes with the development of human activity, which directly threatens human life because of the effects accompanying the development of polluting industries. In response to stakeholder pressures, many companies have taken several actions to reduce the negative impacts of their activities on the environment. Based on the theory of the importance of integrating environment in the strategy of industrial companies, and that any awareness in this field is reflected in actions for the environment, the researchers wonder through this research about the effectiveness of environmental policies adopted by the Tunisian industrial companies.

To evaluate the effectiveness of environmental policies in the industrial sector in Tunisia, the researchers conducted an exploratory study with a sample of Tunisian industrial companies. Thus, the paper was divided into three parts. The first one will discuss the theoretical concepts related to the environmental awareness and the strategic actions witch can be taken for environmental protection. In the second part, we will present the exploratory study conducted within a sample of industrial firms to evaluate their environmental policies. The last part will focus on the analysis and the interpretations of the emerging results.
\end{abstract}

Keywords: Environmental protection, Environmental policies, negative impacts, stakeholder's pressures.

\section{Introduction}

Taking into consideration the environmental dimension into business strategies presents a major challenge for sustainable development policies that consider environmental protection a necessary means to the prosperity of human well-being. With the development of human activity, the environmental changes can even be disturbed, which directly threatens human life because of adverse effects that accompany the development of polluting industries. Stakeholders, who maintain direct or indirect relationships with industry, are becoming increasingly aware of environmental problems. The Stakeholders go further by saying that all companies must adopt policies and strategies for the protection of the environment.

Gradually, companies under the strong pressure of society have become aware of risks associated with development of their

Copyright (C) 2012 Fakhfakh Hamadi, Amara Tijani and Ben Ali Tarek. This is an open access article distributed under the Creative Commons Attribution License unported 3.0, which permits unrestricted use, distribution, and reproduction in any medium, provided that original work is properly cited. Contact author: Fakhfakh EmailHamadi.fakhfakh@fsegs.rnu.tn 
activities. Their concerns are moving towards minimizing the negative effects of their production on the environment. Although this awareness is not yet generalized for all firms, Andre Pierre (1999) confirms that the majority of them considered that respect for the environment is a competitive factor enabling the company to control regulatory, economic, fiscal and social pressure. This orientation is, in fact, a crucial step towards the integration of the concept of sustainable development into business strategies. This integration aims to preserve resources for future generations and improve the social and environmental performance of companies.

Based on these findings of the importance of integrating environment in the strategy of industrial companies and that any awareness in this area is reflected in actions for the environment, the researchers investigate through this paper the effectiveness of environmental policies adopted by the Tunisian industrial companies. To judge the effectiveness of environmental policies in the industrial sector in Tunisia, the work was divided into three parts. The first will discuss the theoretical concepts related to environmental awareness and strategic actions that can be taken to protect the environment. In the second part, the research methodology follows. The last part will focus on the analysis and interpretation of results witch emerged from a field survey.

\section{Environmental Policy: A Necessity or a Choice for the Company?}

The researchers use, as part of this work, the concept of environment which refers to everything that surrounds the human being as defined by Webster "the environment is all natural and cultural conditions likely to act on living organisms and human activities. "This section seeks to understand the importance of environmental policies for the company. Three stylized facts are successively addressed:

- The concept of environmental awareness;
- The reasons supporting the inclusion of the environment in the development strategies of enterprises;

- The behavior of the company with a view to environmental awareness.

\section{The Environmental Awareness}

After the Second World War, there was a wave of concern about what humans are doing to the planet. Fortin. J. (1995) emphasizes that the great movement for the environment was arising. A series of conferences held, first in Stockholm in 1972 and then in Rio in 1992 and 2005 where academic and political men met to discuss issues of environmental policies and to mobilize public opinion in favor of environmental preservation. Thus, the sense of a fragile earth, more and more degraded by the residues of human activities spread gradually. This feeling stems from several major industrial accidents with environmental consequences that are still valuable to the present. In 1966, at Feyzin in the Lyon region, an explosion of liquefied gas under pressure caused eighteen deaths and in 1984, a cloud of toxic gas killed more than 3000 people and nearly 300,000 injured in Bhopal (India). In 1986, the disaster of "Chernobyl" took place (Mundler and others, 1997).

The impact of these events was strong enough but environmental hazards, particularly due to waste and nonconservation of economic resources and the pollution of air and water coexist always with us in a more accelerated rate. Today we are witnessing a change in the social interest. The public is trying to regain its power of reflection and criticism. We speak today of a "synchronic solidarity with the present generation, a diachronic solidarity with future generations and ethics also based on the universality of citizenship" (Sachs, 1987). With this awareness, many countries have responded in favor of conscious protection of the environment by developing more standards, more or less restrictive in this 
regard. Companies are called to meet social needs. They can take an important part in the construction of social ethics and therefore the speed of the adoption of measures for the protection of the environment.

Business in preserving the environment requires the company to act as a responsible citizen to both the realization of the benefits and realizing that it does not operate in a sociological vacuum. This leads to rights but also duties. In other words, when the company is socially responsible and is making a profit, it creates wealth for its own and the society. It is, in fact, the trend towards the Pareto-efficient behavior expected by the modern societies of their economic actors. Currently, there is also talk about environmental auditing as a management tool comprising a systematic, periodic and objective performance of programs on environmental management systems equipment. This evaluation is, according to ICCA (1992), to verify compliance with company policies and facilitate the control of the manager of environmental practices. According to Williams et al(1999), it seems that the information on the environment is much sought by those concerned. Some studies show that many investors are interested in environmental protection. Some countries, including Tunisia, require a feasibility study of any new project, showing not only its profitability but also its impact on the environment. Rubinstein (1991) asserts that a growing group of users of financial statements in the company calls for the presentation of information that is essential for the analysis of environmental concerns. The balance between the current consumption and the conservation potential of consumption for future generations is a challenge for economists. The capital stock consisting of both artificial elements and elements of nature must not decrease. It must remain at least constant (Mundler et al 1997).

In fact, the technical possibilities of substitution are uncertain and technological change can-not guarantee absolute substitution between factors. This justifies the fact that a technology policy is concerned with the preservation of the environment, to play an important role in business strategies. According to Porter et al (1995), making a clean environment is, in fact, "a significant competitive advantage compared to other pollutants."

The government has also actively contributed to the increase of environmental awareness of the companies. Vermersch (1996) emphasizes that environmental awareness and concern for environmental preservation preside over all the talk, dominate all discussions. According to this author, environmental issues are becoming key variables of public policy and influence individual behavior. Protecting the environment is an ethical objective taking into account public values chosen collectively. Drechsler (2002) considers that environmental regulations should be the key to the completion of efforts to prevent exceeding acceptable environmental limits. Legal measures and institutions for environmental purposes are increasing both nationally and internationally in countries such as in the developing countries. The growing media coverage of the environment plays an important role during this period. Changes in terms of «nature» to «environment» and «living» are not without impact on populations. It is this dynamic of actors that has held the Stockholm Conference in 1972. It extended the discussion begun in 1968 with emphasis not only on the scientific aspects of environmental problems, but also on political, sociological and economic aspects.

The Reasons Supporting the Inclusion of Environmental Business Strategies

According to Marchetti (2006), environmental responsibility of business is a required topic in the reflection of the society towards the globalization of economic systems and the financial market crisis. According to Marchetti, these two factors 
contributed to the emergence of new theories of economic and social development.

The global market and extending the role of foreign capital investors in the structuring of the new economy do not necessarily lead to a more equitable distribution of wealth. This can, however, lead to economic and social inequalities at the international level (Melchior, 2001). In a global Economy, the traditional forms of wealth distribution are failing because the wealth produced in some countries moves to other countries (Marilena 2008). Multinational companies with headquarters in developed countries, produce, and buy raw materials in the developing countries; they use the companies in these countries as indirect suppliers. The level of benefit costs in developing countries, compared with that of developed countries, is partly due, according to Sacconi (2003), to the lack of social and environmental standards required in developed countries and standards protection of stakeholders. Globalization is, in this sense, an accelerated process of economic integration, whose consequences are reflected in the sustainable development that requires large companies to introduce corrections in their social activity.

Contrary to expectations under globalization, Marilena (2008) points out that, the global financial market crisis is driven by an irrational exuberance of investors, such as the 2008 financial crisis. These crises have demonstrated the ineffectiveness of the directors of several companies that have distorted accounts to show high levels of performance increasing the value of the securities in order to attract more investors. Even the proposed techniques such as stock options and executive compensation based on their performance could not, in fact, align the interests of the managing directors with those of shareholders. In this context, Marilena (2008) notes that they have caused many losses to minority shareholders, who did not belong to the control group of leaders at all business partners, consumers and the community where these companies were operating. The series begins with the black spectacular failure of the gigantic economic group "Enron Corporation". This has also affected WorldCom (the most dramatic bankruptcy in the history of the United States), Tyco International, Qwest, Xerox, American Series, Universal Vivendi, Ahold and Parmalat in Europe (Feleaga, N., 2006). These crises have led to a lack of confidence in the reliability of the information provided by accounting. For Phillips (2003), the information provided cannot catch all the dimensions of performance and highlighted the dissociation between accounting, ethics and responsibility of leadership. As a result, and to address the financial crisis and false accounting information, the company requires the disclosure of information summarizing the performance indicators that reflect the practices of corporate environmental responsibility.

The contemporary world has experienced a change of economic system based primarily on material and financial resources towards a system where performance has become conditioned by intangible resources. In this context, Melchior (2001) shows that the global economic system is in progress to become a system of ideas and technological innovations where the potential of intellectual capital is becoming a competitive lever for the economic survival of the company. In the same vein, Janicot (2007) reports that the stock price increases, when the value of the intangible resources of a company increases. In addition, natural capital is considered essential for the functioning of the contemporary economic system. However, humanity has been for some-time ignorant and unable to mobilize the intelligence and resources to restore the ecological balance. The spirit of solidarity warranty regarding the capabilities of present and future generations to use the natural resources is needed to maintain the quality of life.

According to Turner et al (2003), the present generation must pass on to future generations a stock of resources equivalent 
to that which it operates. Passing the interests of the present generation to those of the future generations must not sacrifice the first, but rather to affirm the ethical principles. However, human behavior is an obstacle in preserving resources for future generations. For Poli (1994) changing human behavior to the objective of fairness between and within generations has been reached. The social contract between generations is considered essential for sustainable development and efficiency.

\section{Efforts to Protect the Environment}

In response to stakeholder pressures, companies have implemented several actions to reduce adverse impacts of their activities on the environment including the adoption of clean technologies and implementation of environmental management systems. Clean technologies are new industrial processes or changes to existing processes implemented to reduce the environmental impact of productive activities, including reducing energy and raw materials. Such technology allows, according to Cagnon et al(2005), to reduce pollution at source and even prevent it. The term source reduction means any practice that reduces the amount of hazardous substances or pollutants. This reduces, in fact, the danger to the society and the environment.

The concept of "clean technology" is recognized internationally in the policy of sustainable development as defined in Agenda 21, adopted in Rio de Janeiro in 1992. The text strongly encourages companies to use clean technologies in the form of practical knowledge and scientific tools for cleaner production in a particular area. According to Valerie et al (2005), clean technologies are modernized production processes and less polluting, more economical and consistent with legislative constraints by integrating either the recovery of raw materials or waste recovery, witch is inexorable. Van Berkel (2000), reports that technologies essentially affect the production process of the company. For him, this is where pollutants of production emerge.

As for environmental management, it is a voluntary process of the company to bring coherence to all environmental actions. For Dupraz et al(2004), the implementation of dashboards used to monitor actions taken and and the results achieved. Environmental management aims to take into account the impact of company activities on the environment to assess and reduce it. It is therefore essential to integrate environmental management and corporate strategy. This approach corresponds, in fact, to the expectations of stakeholders, providing on the one hand robust tools for analysis diagnosis and assistance in developing goals, and on the other hand, action plans or new procedures, the development of organizations, monitoring and evaluation activities.

In a society, which has become anxious to preserve its natural heritage, environmental management can be a good card, generating a positive image. It represents, therefore, a financial investment that the costs could be compensate by streamlining practices and good cost control induced by the approach taken (Eglantine, 2003). The environmental management system (EMS) is used to establish a good regulatory management and reduce criminal risk. It responds well, to the requirements of public authorities in terms of environmental impact. Therefore, it allows the company to access new markets and build trust relationships with its customers and stakeholders. This leads ultimately to lower costs of marketing and public relations. According to Eglantine (2003), "the establishment of an EMS can be an opportunity to identify new needs that may initiate the creation of new activities." This results in job creation and a suitable reorganization of human resources. 


\section{Presentation of the Study Background and the Research Methodology}

\section{The Study Background}

Since the 60s, several green waves were triggered following the degradation of the environment by human activities especially those of industrial origin. These waves are expressed by pressure on companies to reduce their negative externalities generated by their activities and then preserve the natural environment. Henriques et al (1999) identify four groups of sources of pressure namely green partner's regulatory, organizational partners, community partners and the media. According to the authors, business leaders emit an effective strategy when the pressures come from all partners. According to Fischer et al (1993), these pressures vary in intensity depending on the country, the industry and even the firm.

For each country, the environmental issue presents a particular aspect. Thus, it does not present in Tunisia the same characteristics as those might be encountered in other countries. The problem of the environment in Tunisia arises in a very acute manner for several reasons, including resource scarcity, population growth and pollution.

For scarce resources, the natural Tunisian resources seem to be devoid from water, such as rivers and lakes. This is indeed, the consequence of a massive consumption of water by industry and in particular the production of phosphate and sulfuric acid. This situation has created a water shortage, causing a process of desertification. Thus, the phenomenon of soil erosion has contributed to the degradation of fertile land. For its part, the population growth causes urbanization, with the pace of change faster than the population growth with a concentration in larger cities, which created a source of nuisance polluting. In addition, the Tunisian industrial companies and particularly those operating in the chemical sector, contributes to the increase of air pollution that generated several diseases in the short and long term, including cancer.

In Tunisia, the green wave is relatively recent. Indeed, it is in the early 1990s that the Tunisian government has introduced environmental legislations. For this propose, the National Agency for the Protection of the environment (ANPE) was created. The Tunisian government had also issued many regulations governing several problems that may face the environmental framework such as the law No. 96-41 of 10 June 1996 on waste and control of their management and their disposal; the Decree No. 2000-2339 of 10 October 2000 establishing the list of hazardous waste; the Decree No. 2003-1718 of 11 August 2003 fixing the general criteria for the manufacture; the law No. 75-16 of 31March 1975, promulgating the Water Code, the Decree No. 85-56 of 2January 1985, concerning the regulation of discharges into the receiving environment, the framework law on air Quality (June 2007) and the Decree No. 2005-1991du 11 July 2005 establishing the study of the environmental, impact of industrial projects.

Although the Tunisian Government provides grants to businesses that contribute to reducing its negative effects on the environment, the inclusion of an effective policy for the protection of the environment in corporate strategy remains low and sometimes negligible for few companies operating in the industrial sector in particular. In addition to this factor, there is the relatively low-pressure community on corporate polluters. Currently, the community emphasizes the employability of a clean environment. This is justified by the high rate of unemployment in Tunisia. This work seeks to identify the extent to which Tunisian industrial companies adopt policies of environmental protection. 
To judge the effectiveness of environmental policy in the industrial sector in Tunisia, an exploratory study through a questionnaire was conducted in a sample of managers of industrial enterprises in Tunisia. It is through this empirical investigation that the researchers can identify and analyze the behavior of industrial enterprises in Tunisia vis-à-vis the environmental dimension. Before presenting the results of this research, the researchers will present successively: the study sample, the statistical tools used, the conceptual frame of reference and assumptions of the investigation.

\section{Presentation of the Sample}

The Tunisian industrial sector has regained its momentum over the last decade. The increasing number of companies and diversification of their activities characterized this period. The statistical data to the portal of Tunisian industry are 5861 firms of different sizes with a number greater than or equal to 10 employees of which 2775 are totally exporting companies. According to statistics established by the Minister of Industry and Energy and SMEs (2010), nearly $20 \%$ of Tunisian industrial enterprises as polluting and notes that of these, $70 \%$ are classified as highly polluting. For the purpose of this research, the researchers selected a sample of firms belonging to the group of firms classified as highly polluting. The majority of companies surveyed are among the top 500 companies in Tunisia in 2010 . The survey was designed to be disseminated to a large number of companies operating in the industrial sector.

The questionnaire was tested for accuracy and to see if any necessary changes were necessary. Therefore, it was administered by telephone with a score of business that was used to test the operationalization of the questions and some changes were made to the questionnaire for a better understanding of its contents. The final questionnaire was administered to 500 Tunisian industrial companies (via direct contact and e-mail) belonging to different regions of the country.
One copy per company was distributed. This is justified by the fact that only one in charge is responsible for the environmental dimension. It may be the manager responsible for environmental or health safety within the company. The number of questionnaires collected was 182 copies, representing a rate of $36.4 \%$ of the total sample.

\section{The Statistical Tools Used}

Tools and statistical methods are needed to support the analysis to be conducted in the present study. The researchers opted for the software SPSS 17.0 for data processing of the questionnaire. They used principal components analysis to test the hypotheses of the study. This is an econometric technique to summarize as much original information (variance) as in a minimum number of factors.

With a view to interpret the factors that the principal component analysis suggests, a linear regression analysis is performed to explain a quantitative variable by another quantitative variable.

Gains and losses are used to verify the contribution of each exogenous variable in the variation of the endogenous variable. It may be verified through discriminated analysis that involves studying the relationship between a nominal dependent variable and a set of explanatory variables (quantitative) and proportion of intervals. At the global level, the coefficient of determination R2 will explain the part of the variable $\mathrm{Y}$ explained by the variation of $\mathrm{Xi}$. Then, the Fisher test paves the way to assess the significance of the results.

\section{The Conceptual Framework for Modeling the Environmental Fate}

Adopting a responsible environmental policy involves changes in attitudes, values and visions and an indication of sustainable intention. Knowing the determinants of environmental policy will facilitate, indeed, 
the establishment of an effective environmental strategy.

The majority of theoretical works that focus on the study of environmental policy refers to the theory of planned behavior of Ajzen (1987, 1991). This theory states, according to Ajzen (1991), that the intention to behave is a direct determinant of the action. Thus, it aims to predict the behavior of individuals by identifying individual and contextual factors that determine them. According to Ajzen (1991), the prediction of behavioral intention is made through three components namely attitudes related to behavior, subjective norms and perceptions of behavioral control. Being a part of the present research, the adoption of the theory of planned behaviour as a theoretical framework is deemed appropriate. Tunes (2001), for example, confirms that the theory of planned behavior was used with great success in empirical and fundamental research. The following table summarizes the components of the environmental policy.

\section{Table 1: The Components of the Environmental Policy}

\begin{tabular}{|l|l|}
\hline Elements & Components \\
\hline Attitudes associated with behavioral & Environmental awareness \\
\hline Subjective standards & $\begin{array}{l}\text { Pressure from stakeholders and } \\
\text { regulations }\end{array}$ \\
\hline Perceptions of behavioral control & $\begin{array}{l}\text { The actions taken to protect the } \\
\text { environment }\end{array}$ \\
\hline
\end{tabular}

\section{Description of the Assumptions of the Study}

The researchers recall that the main objective of this study is to evaluate environmental policies for industrial companies in Tunisia, as a trigger of the cognitive process, leading to environmental actions and practically coherent and relevant.
This paper's hypotheses were defined according to the model of the theory of planned behavior (Ajzen, 1987, 1991), adapting them to the variables of interest and context study. Figure 1 describes the conceptual model that was tested.

\begin{tabular}{|c|c|c|c|}
\hline \multicolumn{2}{|c|}{$\begin{array}{c}\text { (Base hypotheses) } \\
\text { Tunisian industrial companies adopt environmental policies into their } \\
\text { development strategies. }\end{array}$} & \multirow{2}{*}{ First step } \\
\hline HP1 & HP2 & \multirow{2}{*}{ Second step } \\
$\begin{array}{c}\text { Tunisian industrial } \\
\text { the environmental } \\
\text { dimension }\end{array}$ & $\begin{array}{c}\text { There are reasons for } \\
\text { supporting the } \\
\text { inclusion of the } \\
\text { environmental } \\
\text { dimension. }\end{array}$ & $\begin{array}{c}\text { Tunisian industrial } \\
\text { companies } \\
\text { undertook strategic } \\
\text { actions for the } \\
\text { environment }\end{array}$ & \\
\cline { 1 - 3 } $\begin{array}{c}\text { Attitudes associated } \\
\text { with behavioral }\end{array}$ & Subjective norms & $\begin{array}{c}\text { Perceptions of } \\
\text { behavioral control }\end{array}$ & \\
\hline
\end{tabular}

\section{Graphic 1: Structure of Research Hypotheses}

The basic hypothesis (BH) of the survey, based on the work of Lafontaine (2006), is:

The Tunisian industrial companies adopt environmental policies into their development strategies.
According to the model of planned behavior adopted, the determinants of environmental policy are in the order of three key variables (Figure 1): 
- Attitudes associated with behavior are dependent on environmental awareness (Chapuy 2003 and Swift et al 2004);

- Subjective norms are manifested primarily by compliance with environmental regulations and pressure from stakeholders (Marilena, 2008);

- Perceptions of behavioral control are associated with the degree of response of firms to environmental problems (Gendron, 2004);

Through the verification of the hypothesis, the three variables are expected to have a significant effect on the adoption of environmental policies from the Tunisian industrial companies. The researchers aim to test this hypothesis and to identify the relative contribution of each of these variables to the explanation of environmental policies. The three sub-hypotheses are:

HP1: Tunisian industrial companies are aware of the environmental dimension.

HP2: There are reasons for supporting the inclusion of the environmental dimension.

\section{HP3: The Tunisian industrial companies have taken strategic actions for the environment.}

For measuring the environmental policies, the researchers used a Likert scale with three positions:

\& For the attitudes associated with behaviors "environmental consciousness", they were measured by 06 items reflecting the degree of awareness of enterprises in terms of the environmental certificates and the ability of firms to control and evaluate the negative effects of their activities on the environment.

* On the measurement of subjective norms "of the reasons supporting the inclusion of the environment", 06 items was used to describe the influences on the company so that it takes into consideration the environmental dimension in the strategy as the pressures of internal and external stakeholders and environmental regulations.

* As for the "degree of response of firms to environmental problems", it was measured using 06 items that describe the major actions taken to protect the environment such as awareness training, and green products publication of environmental information in financial reports of the company.

\section{Analysis and Interpretation of Results}

To ensure scientific rigor, was necessary to test the reliability of the measurement scale. Reliability refers to the degree of stability of a measure for an indefinite period and regardless of the interviewees. Thus, an action will be reliable only if it is understood and interpreted identically by all participants in the survey. As for convergent validity, it is ensured when the measures of the same concept are converging in terms of correlation. In the first step, the researchers have verified that the measurement scales used were reliable. The assessment scales can be performed using the calculation of Cronbach's alpha. Jolibert and Jourdan (2006) see that reliability is the ability to scale to reproduce the same result when applied several times to measure the same concept. According to Evrard et al (2003), an alpha between 0.6 and 0.8 is acceptable for an exploratory study.

To test our hypotheses, the researchers proceeded in stages. The validation of the assumption (HB) was performed by regressing the variable measuring "environmental policy" on its three determinants. However, before testing this assumption, it seems more appropriate to test first the other three hypotheses (HP1, HP2 and HP3). In fact, their validation required the principal component analysis 
(PCA) to reduce the amount of information by combining the various determinants measured at a limited number of factors. Then, for each variable measuring environmental policy, it was regressed on its factors identified by the AF.

\section{Environmental Awareness}

The principal component analysis (FACTOR ANALYSIS) extracts four factors explaining the environmental awareness of Tunisian industrial companies. These factors explain almost $84 \%$ of the total variance and are as follows:
- Factor 1: "Environmental responsibility and certification"

- Factor 2: "Stakeholders and internal impact assessment"

- Factor 3: "environmental regulations"

- Factor 4: "Environmental Culture"

To identify significant relationships between exogenous variables (factors retained) and endogenous (Environmental Awareness), the researchers relied on multiple regression analysis. Table 1 presents key statistics on the first model (M1), testing the relationship between environmental awareness and the four factors identified by the CPA.

Table2: Descriptive Statistics for Reporting the Adjustment Concerning the Hypothesis HP1

\begin{tabular}{|c|c|c|c|c|c|c|c|c|c|}
\hline & & & & & \multicolumn{5}{|c|}{ Statistiques } \\
\cline { 5 - 11 } Model & $\mathrm{R}$ & $\begin{array}{c}\text { squar } \\
\mathrm{e}\end{array}$ & $\begin{array}{c}\text { R square } \\
\text { adjusted }\end{array}$ & $\begin{array}{c}\text { standard Error } \\
\text { of' estimation }\end{array}$ & $\begin{array}{c}\text { R square } \\
\text { Change }\end{array}$ & F Change & df1 & df2 & Sig. F \\
Change
\end{tabular}

Source: Output of the Software Estimation

The regression results indicate, for the reference population, a good correlation between environmental awareness and the factors considered. The intensity of this relationship results in a correlation coefficient $\mathrm{R}$ whose value is $65.7 \%$. The adjusted R2 has an acceptable score of 0.424 . This result indicates that the model reproduces $42.4 \%$ of the variation expressed in the input data.

To appraise the quality of adjustment of this regression, the $\mathrm{F}$ test of Fisher was deployed. The critical value of $F$, the threshold $\alpha=0.01$ for 4 and 177 degrees of freedom is equal to 4.31. The calculated F $(56680$, sig. $=0.000)$ significantly higher, can concluded that the quality of adjustment provided by the regression is significant. Therefore, there is a significant dependence between environmental awareness and the factors that determine it, retained by the CPA. To assess the contributions of each of them to the overall explanation of the model, the researchers calculated the values of partial coefficients of multiple regression with values reported in Table 2. 
Table 3: Coefficients for the First Partial Adjustment Model (M1)

\begin{tabular}{|c|c|c|c|c|c|}
\hline \multirow[t]{2}{*}{ Modèl M1 } & \multicolumn{2}{|c|}{$\begin{array}{l}\text { Non standard } \\
\text { Coefficients }\end{array}$} & \multirow{2}{*}{$\begin{array}{c}\begin{array}{c}\text { Standard } \\
\text { Coefficients }\end{array} \\
\text { Beta }\end{array}$} & \multirow[t]{2}{*}{$\mathrm{t}$} & \multirow[t]{2}{*}{ Sig. } \\
\hline & B & Std Error. & & & \\
\hline $\begin{array}{l}\text { Environmental responsibility and } \\
\text { certifications }\end{array}$ & 0,208 & 0,024 & 0,380 & 6,642 & 0,000 \\
\hline $\begin{array}{l}\text { The internal stakeholders and assess their } \\
\text { impacts }\end{array}$ & 0,131 & 0,024 & 0,238 & 6,067 & 0,000 \\
\hline The environmental regulations & 0,238 & 0,024 & 0,208 & 4,348 & 0,000 \\
\hline The environmental culture & 0,050 & 0,024 & 0,433 & 1,529 & 0,128 \\
\hline
\end{tabular}

Examination of values for adjustment factors indicates that the factor "environmental responsibilities and certifications," explains almost $21 \%$ of the variation in environmental awareness. For the factor "internal stakeholders and assessing their impact", it contributes $13.1 \%$ to the overall explanation of the model. The third factor "environmental regulations» has a predictive power to the order of $24 \%$. However, the contribution of the fourth factor, "environmental culture" is very small and insignificant (5\% only). Although econometrically we can eliminate the factor of environmental culture overall explanation of the model, in practice a great question arises: how can this weak environmental culture among Tunisian industrial companies be explained?

Two supporting reasons can be logically proposed. On the one hand, the environmental management system in Tunisian firms is in its infancy and contractors have not yet been confident enough of its importance. On the other hand, to ignite a environmental spark, companies must have regular and firm information and training in environmental culture and be especially encouraged to make use of this information. The role of government is crucial, through its direct and indirect interventions in the spread of an environmental culture among companies.
The researchers have, thus, according to the regressions already advanced, confirmed the existence of a significant and positive effect of the three-selected explanatory factors (environmental responsibility and certifications, internal stakeholders and assessing their impacts and environmental regulations) on the endogenous variable "Environmental awareness".

\section{The Reasons Supporting the Adoption of An Environmental Policy}

The principal component analysis revealed a four-factor solution $(82.50 \%$ of the total variance):

- Factor 1: "influence of external stakeholders."

- Factor 2: "competition and environmental regulations."

- Factor 3: "the environment and overall performance."

- Factor 4: "influence of internal stakeholders."

For the present study, the dependent variable is the reasons supporting the inclusion of the environmental dimension and the explanatory variables are those identified and agreed by the Factor Analysis. The regression test whose characteristics are of basic statistics are shown in Table 3. 
Table 4: Descriptive Statistics for Reporting the Adjustment Concerning the Hypothesis HP2

\begin{tabular}{|c|c|c|c|c|c|c|c|c|c|}
\hline \multirow[b]{2}{*}{ Model } & \multirow[b]{2}{*}{$\mathrm{R}$} & \multirow[b]{2}{*}{$\begin{array}{c}\mathrm{R} \\
\text { square }\end{array}$} & \multirow[b]{2}{*}{$\begin{array}{l}\text { R square } \\
\text { adjusted }\end{array}$} & \multirow{2}{*}{$\begin{array}{l}\text { standard } \\
\text { Error of' } \\
\text { estimation }\end{array}$} & \multicolumn{5}{|c|}{ Statistiques } \\
\hline & & & & & $\begin{array}{c}\text { R square } \\
\text { Change }\end{array}$ & F Change & df1 & df2 & $\begin{array}{c}\text { Sig. F } \\
\text { Change }\end{array}$ \\
\hline M2 & 0,683 & 0,467 & 0,459 & 0,35715 & 0,467 & 65,379 & 4 & 177 & 0,000 \\
\hline
\end{tabular}

Source: Output of the Software Estimation

The test regression reveals a strong correlation $(\mathrm{R}=68.3 \%)$ between the dependent variable which is the reasons supporting the inclusion of the environment and the factors that explain it. The expression of this relationship results in a correlation coefficient R2 of $46.7 \%$. The adjusted R2 has an acceptable score of 0.459 , indicating that the model explains almost $50 \%$ of the variation expressed in the input data. To assess the quality of adjustment of this regression, the Fisher test was employed. According to Patton (2001) this explains if, for the risk $\alpha$ considered, the multiple R2 is significantly different from 0 . The critical value of $F$, the threshold $\alpha=0.01$ for 2 and
279 degrees of freedom is equal to 8.339 . The calculated F (65 379, sig. $=0.00)$ being significantly higher, the researchers can confirm that the quality of adjustment provided by the regression is significant. There is therefore a significant dependence between the reasons supporting the inclusion of the environment and the four factors representing its determinants. The analyses by the technique of multiple regressions allow determining the perceived ability of each factor used in explaining the variations of the reasons supporting the inclusion of the environment. The results obtained by the regression are presented in Table 5.

Table 5: Values of Coefficients for the Second Partial of the Adjustment Model (M2)

\begin{tabular}{|c|c|c|c|c|c|}
\hline \multirow[b]{2}{*}{ Model M2 } & \multicolumn{2}{|c|}{$\begin{array}{c}\text { Non standard } \\
\text { Coefficients }\end{array}$} & \multirow{2}{*}{$\begin{array}{c}\begin{array}{c}\text { Standard } \\
\text { Coefficients }\end{array} \\
\text { Beta }\end{array}$} & \multirow[b]{2}{*}{$\mathrm{t}$} & \multirow[b]{2}{*}{ Sig. } \\
\hline & B & Std Error. & & & \\
\hline Influence of external stakeholders & 0,289 & 0,021 & 0,398 & 6,642 & 0,000 \\
\hline $\begin{array}{l}\text { Competition and environmental } \\
\text { regulations }\end{array}$ & 0,197 & 0,021 & 0,363 & 6,067 & 0,000 \\
\hline $\begin{array}{l}\text { The environment and the overall } \\
\text { performance }\end{array}$ & 0,141 & 0,021 & 0,260 & 4,348 & 0,000 \\
\hline Influence of internal stakeholders & 0,050 & 0,021 & 0,091 & 1,529 & 0,128 \\
\hline
\end{tabular}

Source: Output of the Software Estimation

Examination of the regression coefficients indicates that the factor "influence of external stakeholders' best explains the reasons supporting the inclusion of the environment (28.9\%). The factor "competition and environmental regulations" contributes $19.7 \%$ to the overall explanation of the model. The search for an overall performance has a share of $14.1 \%$. However, the contribution of the influence of internal stakeholders is very small and insignificant. This leads us to eliminate the factor, internal stakeholders from the overall explanation of the model. In fact, the influence of reliable internal stakeholders in environmental policy fits well with the reasons supporting a weak environmental culture previously discussed. 
There is a positive and significant correlation between the variable representing the reasons supporting the inclusion of environmental business strategies and the variables that explain the influence of external stakeholders, competition and environmental regulations, the environment and overall performance. Consequently, the second hypothesis of the present research, stating that there are reasons for supporting the inclusion of the environment in business strategies, can be accepted.

\section{The Strategic Business}

By applying the Factor Analysis to the items describing the main strategic actions that can be undertaken by industrial firms, the analysis revealed two factors that explain nearly $80 \%$ of the total variance. These factors are:

- Factor 1: "environmental strategy and its impacts"

- Factor 2: "hierarchical structure and environmental culture"

In the current study, the dependent variable is the strategic actions taken by the industrial firms and the explanatory variables are those identified and retained by the Factor Analysis (environmental strategy and its impacts and environmental reporting structure and culture). The regression test (model M3) is presented in Table 5.

Table 6: Descriptive Statistics for Reporting the Adjustment Concerning the Hypothesis HP3

\begin{tabular}{|c|c|c|c|c|c|c|c|c|c|}
\hline & & \multirow{2}{*}{$\mathrm{R}$} & & \multirow{5}{|c|}{ Statistiques } \\
Modèl & $\mathrm{R}$ & $\begin{array}{c}\text { squar } \\
\mathrm{e}\end{array}$ & $\begin{array}{c}\text { R square } \\
\text { adjusted }\end{array}$ & $\begin{array}{c}\text { Error of } \\
\text { estimation }\end{array}$ & $\begin{array}{c}\text { R Square } \\
\text { Change }\end{array}$ & F Change & df1 & df2 & $\begin{array}{c}\text { Sig. F } \\
\text { Change }\end{array}$ \\
\hline M3 & 0,867 & 0,751 & 0,749 & 0,26648 & 0,751 & 270,647 & 2 & 179 & 0,000 \\
\hline
\end{tabular}

Source: Output of the Software Estimation

The test regression reveals a strong correlation $(\mathrm{R}=86.7 \%)$ between the endogenous variable and two explanatory factors. The expression of this relationship leads to a correlation coefficient R2 of $75.1 \%$. The adjusted R2 has an acceptable score of 0.50 . This result indicates that the model reproduces almost $75 \%$ of the variation expressed in the input data. The critical value of $F$, the threshold $\alpha=0.01$ for 2 and 179 degrees of freedom are equal to 3.76. The calculated F (270 647, sig. $=0.000)$ being significantly higher, which enables to confirm the quality of adjustment used is significant.

So, there is a significant dependence between, the strategic actions taken by the industry and the factors behind the interest of adopting an environmental policy. The results are presented in table 6 :

Table 7: Values of Coefficients for the Third Partial the Adjustment Model (M3)

\begin{tabular}{|c|c|c|c|c|c|}
\hline \multirow[t]{2}{*}{ Modèle 3} & \multicolumn{2}{|c|}{$\begin{array}{l}\text { Non standard } \\
\text { Coefficients }\end{array}$} & \multirow{2}{*}{\begin{tabular}{|c}
$\begin{array}{c}\text { Standard } \\
\text { Coefficients }\end{array}$ \\
Beta
\end{tabular}} & \multirow[t]{2}{*}{$\mathrm{t}$} & \multirow[t]{2}{*}{ Sig. } \\
\hline & $\mathrm{B}$ & Std Error. & & & \\
\hline Environmental Strategy and impact & 0,449 & 0,020 & 0,845 & 22,676 & 0,000 \\
\hline $\begin{array}{l}\text { Hierarchical structure and environmental } \\
\text { culture }\end{array}$ & 0,103 & 0,020 & 0,194 & 5,205 & 0,000 \\
\hline
\end{tabular}

Source: Output of the Software Estimation 
As shown in the table above, the values of partial regression coefficients give the contributions of each of the exogenous variables to explain the overall model. The researchers note that the axis "strategy and its environmental impacts" best explains the strategic actions of firms in terms of environmental protection (44.9\%). The factor "hierarchical structure and environmental culture" contributes $10.3 \%$ to the overall explanation of the model.

Thus, and according to the regressions already advanced, the researchers can confirm the existence of a significant and positive effect of selected factors on the endogenous variable "actions taken by industrial firms for the protection of the environment."
The third hypothesis of this research can be accentuated, which provides evidence of the existence of reasons for the inclusion of the environment by companies in the industrial sector in Tunisia.

\section{Checking the Basic Assumption}

To determine the perceived ability of each factor used in explaining the variations in the base case "The Tunisian industrial companies adopt environmental policies into their development strategies" and the assumptions in assessing the environmental policy, the researchers used the technique of multiple regression. The results obtained by the regression are presented in Table 8.

Table 8: Values of Partial Factors Relating to the Fourth the Adjustment Model (M4)

\begin{tabular}{|c|c|c|c|c|c|}
\hline \multirow[b]{2}{*}{ Model } & \multicolumn{2}{|c|}{$\begin{array}{l}\text { Non standard } \\
\text { Coefficients }\end{array}$} & \multirow{2}{*}{$\begin{array}{c}\begin{array}{c}\text { Standard } \\
\text { Coefficients }\end{array} \\
\text { Beta }\end{array}$} & \multirow[b]{2}{*}{$\mathrm{t}$} & \multirow[b]{2}{*}{ Sig. } \\
\hline & B & Std Error. & & & \\
\hline $\begin{array}{l}\text { Tunisian industrial companies are } \\
\text { aware of the environmental dimension }\end{array}$ & 0,372 & 0,026 & 0,398 & 8,642 & 0,000 \\
\hline $\begin{array}{l}\text { There are reasons for supporting the } \\
\text { inclusion of the environmental } \\
\text { dimension }\end{array}$ & 0,294 & 0,026 & 0,363 & 5,067 & 0,000 \\
\hline $\begin{array}{l}\text { Tunisian industrial companies } \\
\text { undertook strategic actions for the } \\
\text { environment }\end{array}$ & 0,342 & 0,026 & 0,260 & 6,348 & 0,000 \\
\hline
\end{tabular}

Source: Output of the Software Estimation

As shown in the table above, the values of partial regression coefficients give the contributions of each of the exogenous variables in explaining the overall model. In this context, the axis "environmental awareness" best explains the environmental policies adopted by the Tunisian industrial companies (37.2\%). The axis "actions undertaken for the environment" contributes with $34.2 \%$ to the overall explanation of the model. Finally, the axis "the reasons were supporting the inclusion of the environment" contributes $29.4 \%$ to the overall explanation of the model. The researchers can therefore confirm that the basic hypothesis of this research provides the existence of an environmental policy in the Tunisian industrial companies.

\section{Conclusion}

It is found, according to the study, the Tunisian industrial companies relatively adopt environmental policies. This is justified by the results highlighting more or less strong environmental awareness and the adoption of strategic actions beneficial to the improvement of environmental quality. 
The results show that the Tunisian industrial companies (the present study sample) were exposed to pressures from external stakeholders for the implementation of conditions for the implementation of environmental policies. The researchers note, also, an interesting result: It exist a poorly controlled component mastered in the process of environmental policies followed by the Tunisian authorities. It is indeed, the low of the environmental culture and the negligible effects of the stakeholders within the concerned companies. By working more on these routes, public authorities and NGOs can greatly improve the feasibility of environmental practices and convince the entrepreneur's self-alignment. However, this observation does not deny the crucial role played by the state, which really helped to take some actions through ecological tax breaks and subsidies in the context of environmental protection.

Environmental legislation has therefore influenced largely the environmental behavior of industrial enterprises. However, the environment in Tunisia remains, for many of the companies surveyed, a threat and an obstacle facing the growth of the company that warrants further streamlining of procedures for state intervention. For officers, the realization of a good overall performance, including the environment, is difficult, if not impossible, to achieve in the short term.

\section{References}

Ajzen, I. (1991). "The Theory of Planned Behavior," Organizational and Human Decision Processes 50, 179-211.

André, P. (1999). “L'Evaluation des Impacts sur l'Environnement - Processus Acteurs et Pratiques,". Canada: Presses internationales polytechniques, p 416.

Cagnon, E., Trucco, P. \& Tardini, L. (2005). "Cleaner Production and Profitability: Analysis of 134 Industrial Pollution
Prevention (P2) Project Report," Journal of Cleaner Production 13, 593 - 605.

Chapuy, P. (2003). "Entreprises et Développement Durable - Prospectives Stratégique des Enjeux Environnementaux," Cahier de Lipsor, Série recherche n ${ }^{\circ}$, CNAM, $75 \mathrm{p}$.

Drechsler, C. (2002). 'Comportement de Protection de l'Environnement et Performances de l'Entreprise Industrielle : Proposition d'une Théorie Particulière de Processus de Décision d'investissement Environnemental,' Thèse de doctorat, Ecole des Hautes Etudes Commerciales.

Dupraze, L. \& Poimboeuf, H. (2004). 'Développement Durable: Implication pour l'industrie,' Technique de l'ingénieur, G200.

Eglantine, S. (2003). "Les Systèmes de Management Environnemental - Synthèse," disponible sur internet : http://www.laplateforme.org/IMG/pdf/SME _synthese.pdf.

Feleaga, N. (2006). 'Criza Financiară la Cumpăna Dintre Secolele XX şi XXI şi Guvernanţa Întreprinderii, Revista,' Economie Teoretică şi Aplicată, Nr. 9. Traduit par Marilena, M. (2008).

Fortin, J., Martel, L. \& Rakotosoa, E. (1995). "Enjeux Comptables de la Question Environnementale," Accounting Ethics Journal. Montréal, Quebec, H3T 1V6.

Gupta, M. C. (1995). "Environmental Management and its Impact on the Operations Function," International Journal of Operations \& Production Management, Vol.15, $\mathrm{N}^{\circ} 8$.

Henriques, I. \& Sadorsky, P. (1999). "The Relationship between Environmental Commitment and Managerial Perceptions of Stakeholder Importance," Academy of Management Journal, Vol.42, N.1, pp.87-99. 
ICCA. (1992). 'La Vérification Environnementale et la Profession Comptable,' Rapport de recherche.

Janicot, L. (2007). 'Les Systèmes d'indicateurs de Performance Entre Communication et Contrôle,' Comptabilité Contrôle Audit, V1, Tome 13.

Jolibert, A. \& Jourdan, Ph. (2006). 'Marketing Research: Méthodes de Recherche et d'études en Marketing,' Paris: Dunod.

Laforest, V. \& Bertheas, R. (2005). “Ambiguïté entre Technologies Propres et Meilleures Techniques Disponibles," revue des sciences Vertigo.

Lapointe, A. \& Gendron, C. (2004). La Responsabilité Sociale d'Entreprise dans la PME; Option Marginale ou Enjeu Vital ?, 7ème Congrès International Francophone en Entrepreneuriat et PME 27, 28 et 29 Octobre, Montpellier.

Marchetti, S. (2006). 'L'Informativa SocioAmbientale nel Sistema Aziendale: Strumenti Comunicazionali,' Bari, Cacucci Editore. Traduit par Marilena (2008).

Marilena, M. (2008). "Social Responsibility and Environmental Ethics: Elements of the Ecological Culture in 21st Century Organizations: A Study of Romanian coCmpanies," MPRA, Munich Personal RePEc Archive.

Martinet, A. \& Renaud, E. (2004). 'Stratégies d'Entreprises et Écologie,' Paris : Economica.

Melchior, A. (2001). "Global Income Inequality: Beliefs, Facts and Unresolved Issues," World Economics, Vol 2, n 3 , juillet septembre.

Mundler, P. \& Lahsen, A. (1997). 'Economie de l'Environnement,' Hachette Livre, Paris Cedex 15.

Phillips, C. V. (2003). "Literature Review Update: External Costs and Benefits," en ligne sur:

www.apec.umn.edu/faculty/wlazarus/sectio n53.pdf.

Poli, C. (1994). 'Etica Ambientali, Teoria e Pratica,' Milano, Ed. Guerini Studio.

Porter, M. E. \& Van der Linde, C. (1995). "Green and Competitive: Ending the Stalemate," Harvard Business Review, N. 73, $\mathrm{n}^{\circ} 5$, p. $120-134$

Pras, B., Evrard, Y. \& Roux, E. (2003). "Market: Etudes et Recherches en Marketing," Paris, Editions Dunod.

Rubinstein, D. B. (1991). 'Une Comptabilité Verte,' CA Magazine, vol. 126, $\mathrm{n}^{\circ} 3$.

Sacconi, L. (2003). 'Dobbiamo Chiedere alle Imprese di Essere Socialmente Responsabili? E Se sì, Come ?,' CELE.

Sackhs, I. (1987). 'Ces Temps et Ces Espaces Qui s'emboitent, une Terre en Renaissance : Les Semences de Développement Durable,' Le monde diplomatique, Savoir $\mathrm{N}^{\circ} 2$.

Tounes, A. (2001). 'Une Modélisation Théorique de l'intention Entrepreneuriale,' VIIèmesJournées Scientifiques du Réseau Entrepreneuriat de l'AUF, "Formation et entrepreneuriat", Ille Maurice, 4 au 7 juillet, pp, 111-123.

Turner, K. R. \& Pearce, W. D. (2003). 'Economia Ambientale,' Bologna, Il Mulino.

Van Berkel, R. (2000). "Cleaner Production for Process Industries," Plenary Lecture.

Vermersch, D. (1996). 'Externalité et PAC : Une approche coasienne,' Cahiers d'Economie et Sociologie Rurales, $\mathrm{N}^{\circ} 38$.

Williams, S. M. \& Ho Wern Pei, C. A. (1999). 'Corporate Social Disclosure by Listed Companies on their Web Sites: An International Comparison,' The International Journal of Accounting 34(3): pp, 389-419. 


\section{Questionnaire}

This questionnaire Concern an academic study about your experience in environmental protection in your company. The overall results of this survey will be used for research Methods in Finance and
Accounting. This is a work which confidentiality and anonymity of information will be scrupulously respected. Thank you for agreeing to complete this questionnaire and participate successfully in the realization of this research.

\section{Part I: Environnemental Awareness}

Have you designated an internal responsible of the environmental?

Yes

No

You have one or more environnemental certificates

\begin{tabular}{|c|l|l|l|l|l|}
\hline $\begin{array}{c}\text { Many } \\
\text { certificats }\end{array}$ & Certificat & & $\begin{array}{c}\text { No } \\
\text { certificats }\end{array}$ & \\
\hline
\end{tabular}

Your company has knowledge of the existence of recognized environmental management systems?

\begin{tabular}{|c|l|c|l|l|l|}
\hline $\begin{array}{c}\text { Good } \\
\text { knowledge }\end{array}$ & $\begin{array}{c}\text { Moderate } \\
\text { knowledge }\end{array}$ & & No knowledge & \\
\hline
\end{tabular}

You follow the guidelines of ISO 14001.

\begin{tabular}{|l|l|l|l|l|l|}
\hline Always & & Sometimes & & Never & \\
\hline
\end{tabular}

Your company can evaluate the impacts of its products and its processes on the environment?

\begin{tabular}{|c|c|c|c|c|c|}
\hline Capable & $\begin{array}{c}\text { Relatively } \\
\text { capable }\end{array}$ & $\begin{array}{c}\text { Not } \\
\text { capable }\end{array}$ & \\
\hline
\end{tabular}

The environmental dimension is important for internal stakeholders?

\begin{tabular}{|c|c|c|c|c|c|}
\hline Importante & & $\begin{array}{c}\text { Relatively } \\
\text { importante }\end{array}$ & & $\begin{array}{c}\text { Not } \\
\text { importante }\end{array}$ & \\
\hline
\end{tabular}

\section{Part Two: The Reasons for the Consideration of the Environment}

Your Company takes into account the environmental dimension of the reasons for supporting

\begin{tabular}{|l|l|l|l|l|l|}
\hline Always & & Sometimes & & Never & \\
\hline
\end{tabular}

The shareholders of your company influence your environmental strategy

\begin{tabular}{|c|c|c|c|c|c|}
\hline Agree & $\begin{array}{c}\text { Relatively } \\
\text { Agree }\end{array}$ & $\begin{array}{c}\text { Not } \\
\text { Agree }\end{array}$ & \\
\hline
\end{tabular}


The pressure of internal stakeholders influence your environmental strategy

\begin{tabular}{|c|l|l|l|l|l|}
\hline Influence & $\begin{array}{c}\text { Relatively } \\
\text { influence }\end{array}$ & $\begin{array}{c}\text { Do not } \\
\text { influence }\end{array}$ & \\
\hline
\end{tabular}

The pressure of external stakeholders influence your environmental strategy

\begin{tabular}{|c|c|c|c|c|c|}
\hline Influence & $\begin{array}{l}\text { Relatively } \\
\text { influence }\end{array}$ & $\begin{array}{c}\text { Do not } \\
\text { influence }\end{array}$ & \\
\hline
\end{tabular}

The market share influence your environmental commitments

\begin{tabular}{|c|c|c|c|c|c|}
\hline Influence & $\begin{array}{l}\text { Relatively } \\
\text { influence }\end{array}$ & $\begin{array}{c}\text { Do not } \\
\text { influence }\end{array}$ & \\
\hline
\end{tabular}

Compliance with regulations influence your environmental strategy

\begin{tabular}{|c|c|c|c|c|c|}
\hline Influence & $\begin{array}{c}\text { Relatively } \\
\text { influence }\end{array}$ & $\begin{array}{c}\text { Do not } \\
\text { influence }\end{array}$ & \\
\hline
\end{tabular}

Achieving an overall performance affect your environmental strategy

\begin{tabular}{|c|l|l|l|l|l|}
\hline Influence & $\begin{array}{c}\text { Relatively } \\
\text { influence }\end{array}$ & $\begin{array}{c}\text { Do not } \\
\text { influence }\end{array}$ & \\
\hline
\end{tabular}

\section{Part Three: Strategic Actions Taken to Protect the Environment}

Your company has undertaken strategic actions to protect its environment

\begin{tabular}{|c|c|c|c|c|c|}
\hline Undertook & & $\begin{array}{c}\text { Relatively } \\
\text { undertook }\end{array}$ & & $\begin{array}{c}\text { Do not } \\
\text { undertook }\end{array}$ & \\
\hline
\end{tabular}

The company's products are friendly to the environnement

\begin{tabular}{|c|c|c|c|c|c|}
\hline Agree & $\begin{array}{c}\text { Relatively } \\
\text { Agree }\end{array}$ & & $\begin{array}{c}\text { Not } \\
\text { Agree }\end{array}$ & \\
\hline
\end{tabular}

Did your company organize the training of environmental awareness?

\begin{tabular}{|l|l|l|l|l|l|}
\hline Always & & Sometimes & & Never & \\
\hline
\end{tabular}

Your company publishes the environmental information in the financial statements

\begin{tabular}{|l|l|l|l|l|l|}
\hline Always & & Sometimes & & Never & \\
\hline
\end{tabular}

The environmental dimension is at the heart of corporate strategy.

\begin{tabular}{|c|c|c|c|c|c|}
\hline Agree & $\begin{array}{c}\text { Relatively } \\
\text { Agree }\end{array}$ & $\begin{array}{c}\text { Not } \\
\text { Agree }\end{array}$ & \\
\hline
\end{tabular}


19 Journal of Organizational Management Studies

You have documentary sources on the environmental impacts of your products, services or subsidized projects?

\begin{tabular}{|c|c|c|c|c|c|}
\hline Agree & & $\begin{array}{c}\text { Relatively } \\
\text { Agree }\end{array}$ & & $\begin{array}{c}\text { Not } \\
\text { Agree }\end{array}$ & \\
\hline
\end{tabular}

You have in your company a department for the control and monitoring of the environmental impacts of the products.

\begin{tabular}{|c|c|c|c|c|c|}
\hline $\begin{array}{c}\text { Officiel } \\
\text { Département }\end{array}$ & & $\begin{array}{c}\text { Similar } \\
\text { Département }\end{array}$ & & $\begin{array}{c}\text { No } \\
\text { Département }\end{array}$ & \\
\hline
\end{tabular}

